\title{
Evaluation of smoking cessation courses for Turkish-speaking migrants in Switzerland
}

T1 Questionnaire

DO NOT FILL IN! (to be filled in by the project team)

Subject number:

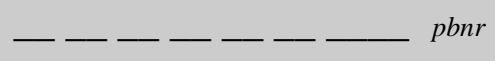

Date of the first course attendance:

$$
-\frac{-}{\mathrm{DD}} \cdot \overline{\mathrm{MM}} \cdot \overline{\mathrm{YYYY}}
$$

t1work_daylwork_montlwork_year 
1. How often do you smoke?

Please tick only one box.

$\square 1 \quad$ Daily

$\square 2 \quad$ Several times per week times per week)

t1-frequently 2

$\square_{3}$ Once a week

$\square 4 \quad$ Less frequently (__ times per month) $\quad$ t1-frequently4

2. How old were you when you a) ...first smoked a cigarette?

years

t1ziga

b) ... started smoking regularly?

years

t1zigb

3. How much do you generally smoke on a day that you smoke?

(a) cigarettes

t1freqzigi

(b) cigars

t1freqziga

(c) _ Pipe

t1freq whistle

(d) __ hookahs

tlfreqw

(e) 'joints' (hashish / 'grass' / cannabis)

t1freqjoi

(f)

E-cigarettes

tlfrequent

4. How soon after waking do you smoke your first cigarette?

Please tick only one box.

$\square 4 \quad$ Within 5 minutes

$\square 3$ Within 6 to 30 minutes

$\square 2 \quad$ Within 31 to 60 minutes

$\square 1 \quad$ After more than 60 minutes 
5. Where and how often do you smoke at home?

Check one box in each line.
a) living room
b) bedroom
c) children's room
$\square_{2} \quad \square_{1} \quad \square 0$
thomea
d) bathroom/ toilet
$\begin{array}{lll}\square_{2} & \square_{1} & \square_{0} \\ \square_{2} & \square_{1} & \square_{0}\end{array}$
tlhomeb
e) kitchen
$\square$
$\square 1 \quad \square 0$
thomec
thomed
f) balcony/ garden/ roof terrace
$\square 2$
$\square 1$
thomee
g) Other room:

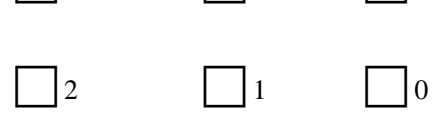
t1homef

frequently rarely never

6. Smoking in a car: Do you or someone living with you own a car?

$\square$ No
$\square 2$ Yes
a) If so, how often do you or other passengers/drivers smoke in the car?

7. How many people live with you in the same household? (including yourself)

Please enter the number:

$\longleftarrow$ Persons living in my household

t1mitbewo

8. How many people who live with you smoke? (including yourself)

Please enter the number: people smoke

t1withbewora

9. Do you have children who live in the same household as you?

$\square_{2}$ Yes

$\square 1$ No

(a) If so, how many children live with you $\longleftarrow$ tlanzki

(b) Age of the children

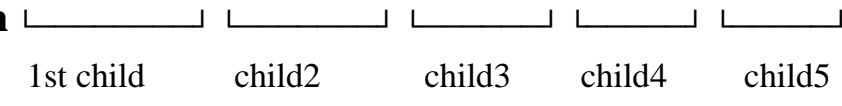


10. How many of your 10 most important family members and friends in Switzerland smoke cigarettes?

Please enter the number:

$\longleftarrow$ people smoke

tlpeople

11. What is your general opinion of smoking? What do you think is best?

Check one box in each line. There are no right and wrong answers. Just express your opinion.

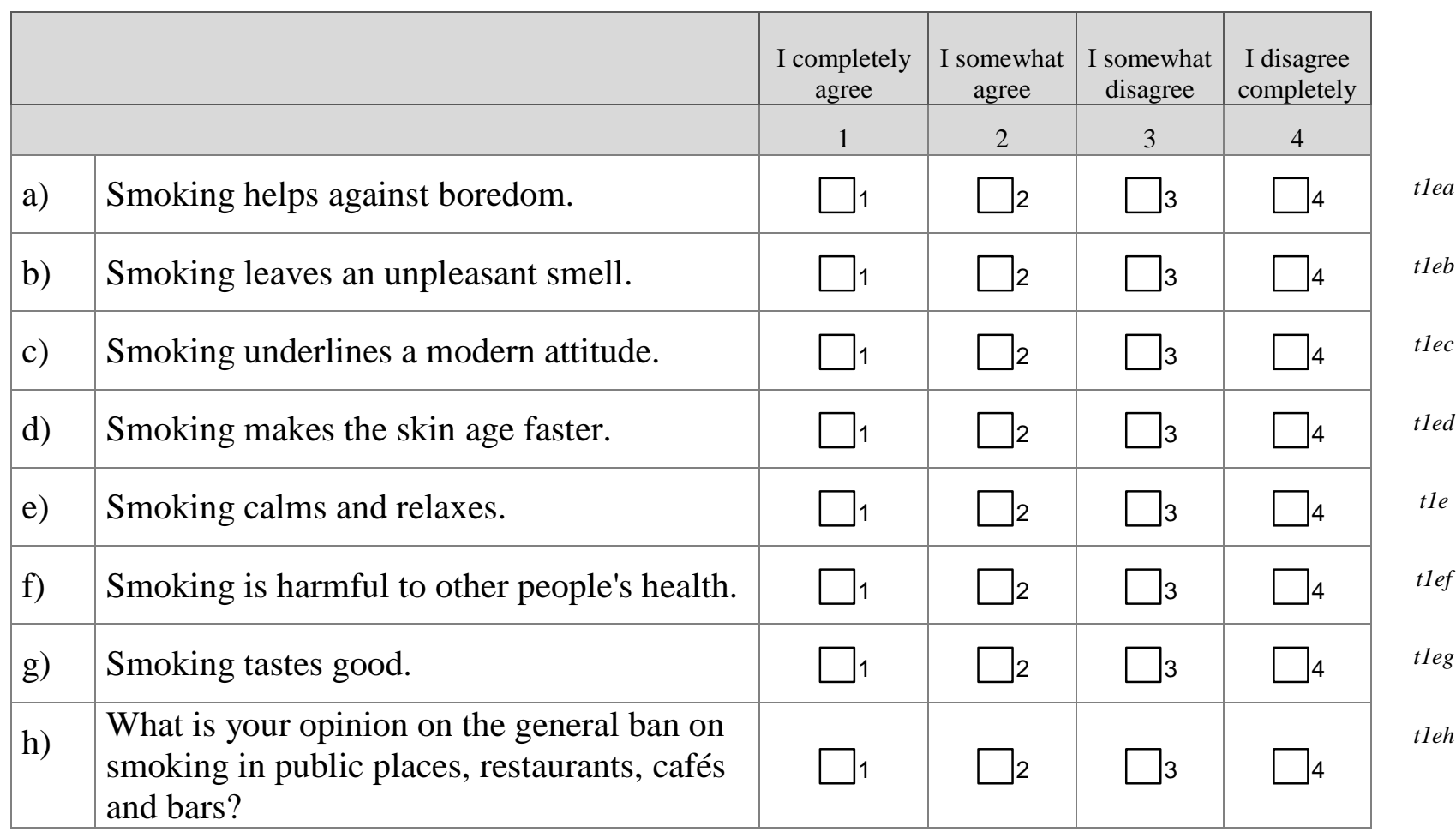




\section{Questions on smoking cessation}

12. Have you ever tried to quit smoking before the stop smoking course?

$\begin{array}{ll}\square 1 & \text { No } \\ \square 2 & \text { Yes }\end{array}$

If so, how often?

Times

t1anzstop

13. How strong is your readiness to quit smoking at this time?

Please circle the number that corresponds to your estimation:

\begin{tabular}{|l|}
\hline $0-1-2-3-4-5-6-7-8-9-10$ \\
$0=$ not ready at all \\
$10=$ I am very ready
\end{tabular}

t1stoptermo

14. What are your expectations to be smoke-free after one year, with the help of this stop smoking course?

Please circle the number that corresponds to your estimation:

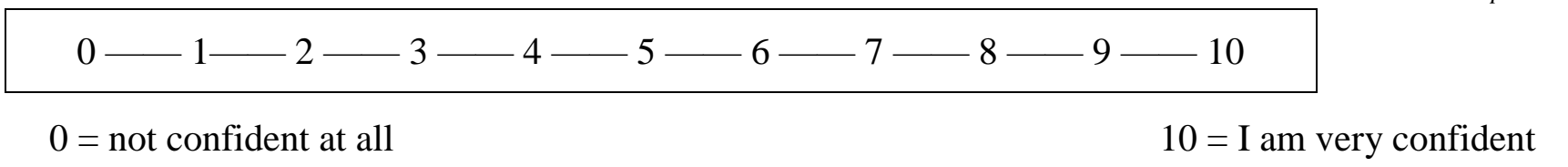


15. Are you a man or a woman?

$\square 1 \quad \operatorname{man}$

$\square 2$ woman

16. How old are you?

years old

17. Are you currently...?

Please tick only one box.

$\square 1 \quad$ Single

$\square 2$ Married, living together

$\square 3 \quad$ Married, living separately

$\square 4 \quad$ Not married, living in a stable partnership

$\square 5 \quad$ Divorced

$\square 6 \quad$ Separate

$\square 7 \quad$ Widowed

18. What is your mother tongue?

Please tick only one box.

1 Turkish

$\square 2$ Kurdish

3 Swiss German/German

4 Other language:

t1 language_off

19. What is your citizenship?

Please tick all that apply
(a) Switzerland
$\square 2$
t1 staata
(b) Turkey
t1stateb
(c) None
t1staatc
(d) Other: 
20. When did you come to Switzerland (year)?

In year

21. What is the highest degree or level of education you have completed?

Please tick only one box.

$\square 1 \quad$ No school

$\square 2$ Primary school (7-12 years)

$\square 3 \quad$ Middle school (10-12 years)

$\square 4 \quad$ Secondary school (15-18 years)

$\square 5 \quad$ College (university)

22. Are you working at the moment?

Please tick only one box.

$\square 1 \quad$ Yes, I work full time (90\% and more)

t1work

$\square_{2}$ Yes, I work part time (less than 90\%)

$\square 3$ No, I am unemployed.

$\square 4 \quad$ No, I am exclusively a housewife/househusband.

$\square 5$ I don't want to say anything about that.

$\square 6 \quad$ No, I am currently in training/school.

23. Where do you currently draw your income from?

Please tick all that apply

Applicable

(a) paid labour

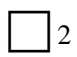

t1incoma

(b) self-employment

$\square 2$

t1incomb

(c) family, kinship

$\square 2$

tleinkomc

(d) friends

t1incoming

(e) welfare, social welfare office, relief agency

tlincome

(f) unemployment benefit

tlincome

(g) other benefits (pensions, IV, etc.)

tlincome

(h) training allowances

t1incoming

(i) Other sources

tleinkomi

(j) I don't want to say anything about that.

t1einkomj 
24. The following questions deal with how often you have been under stress in the last 12 months. (Please tick one answer per statement)

\begin{tabular}{|c|c|c|c|c|c|}
\hline & $\begin{array}{l}\text { Very } \\
\text { often }\end{array}$ & frequently & sometimes & rarely & never \\
\hline $\begin{array}{l}\text { a) In the last } 12 \text { months, how often have you had the feeling } \\
\text { that you were unable to influence important things in your } \\
\text { life? }\end{array}$ & $\square_{4}$ & $\square_{3}$ & & $\square 1$ & $\square 0$ \\
\hline $\begin{array}{l}\text { b) How often in the last } 12 \text { months have you felt confident } \\
\text { in dealing with your personal tasks and problems? }\end{array}$ & $\square_{4}$ & & & $\square 1$ & $\square 0$ \\
\hline $\begin{array}{l}\text { c) In the last } 12 \text { months, how often have you had the feeling } \\
\text { that things are going according to your expectations? }\end{array}$ & $\square_{4}$ & $\square_{3}$ & $\square_{2}$ & $\square 1$ & $\square 0$ \\
\hline $\begin{array}{l}\text { d) In the last } 12 \text { months, how often have you had the feeling } \\
\text { that tasks or problems have accumulated to such an extent } \\
\text { that you cannot cope with them? }\end{array}$ & $\square_{4}$ & & & $\square 1$ & $\square 0$ \\
\hline
\end{tabular}

25. The following statements deal with how well you feel (Please tick one answer per statement)

\begin{tabular}{|c|c|c|c|c|c|c|}
\hline & $\begin{array}{l}\text { Totally } \\
\text { true }\end{array}$ & & & & & $\begin{array}{l}\text { Not } \\
\text { applicable } \\
\text { at all }\end{array}$ \\
\hline & 6 & 5 & 4 & 3 & 2 & 1 \\
\hline a) In general, I feel that I have life under control. & $\square 6$ & $\square 5$ & $\square 4$ & $\square 3$ & $\square 2$ & $\square 1$ \\
\hline $\begin{array}{l}\text { b) I am often overwhelmed with the demands of } \\
\text { everyday life. }\end{array}$ & $\square 6$ & $\square 5$ & $\square 4$ & ]$_{3}$ & $\square_{2}$ & $\square_{1}$ \\
\hline $\begin{array}{l}\text { c) I do not fit in well with the people and society } \\
\text { around me. }\end{array}$ & $\square_{6}$ & $\square_{5}$ & $\square 4$ & $\square 3$ & $\square_{2}$ & $\square 1$ \\
\hline d) I can handle everyday tasks quite well. & $\square 6$ & $\square 5$ & $\square 4$ & $\square 3$ & $\square 2$ & $\square 1$ \\
\hline e) My tasks often overwhelm me. & $\square 6$ & $\square 5$ & $\square 4$ & $\square 3$ & $\square 2$ & $\square 1$ \\
\hline $\begin{array}{l}\text { f) I find it difficult to organize my life in a way that I } \\
\text { am satisfied with it. }\end{array}$ & $\square 6$ & $\square 5$ & $\square 4$ & $\square 3$ & $\square_{2}$ & $\square_{1}$ \\
\hline $\begin{array}{l}\text { g) I am very satisfied with the housing situation and } \\
\text { the lifestyle I have created for myself. }\end{array}$ & $\square 6$ & $\square_{5}$ & $\square_{4}$ & $\square 3$ & $\square 2$ & $\square 1$ \\
\hline
\end{tabular}




\section{Questions about your alcohol consumption}

26. How often do you consume alcoholic beverages?

Please tick only one box.

$\square 0 \quad$ Never

$\square 1 \quad 1 \times$ per month or less

$\square 2 \quad 2$ - 4 times a month

$\square 3 \quad 2-4$ x per week

$\square_{4} \quad 4 \mathrm{x}$ or more per week

27. If you drink alcoholic beverages, how much do you typically drink in a day? An alcoholic drink (= standard drink) corresponds, for example, to approx. $3 \mathrm{dl}$ beer (5 vol.\%), 1dl wine or sparkling wine (12.5 vol.\%), 2 cl schnapps (55 vol.\%) or 4 cl liqueur (30 vol.\%).

Please tick only one box.

$\square 0 \quad$ I don't drink alcohol.

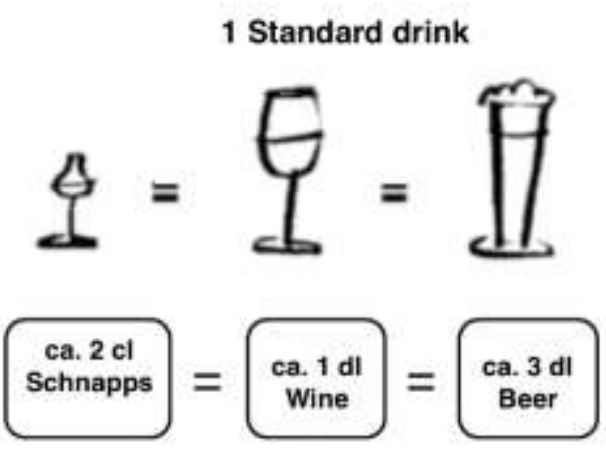

28. How often do you drink 6 or more glasses of alcohol (= standard drink) on one occasion? Please tick only one box.

$\square 0 \quad$ Never

$\square 1 \quad$ Less than 1x per month

$\square 2 \quad 1 \times$ per month

$\square 3 \quad 1$ x per week

$\square 4 \quad$ Daily or almost daily 


\section{Questions about the course}

29. How did you become aware of our smoking cessation course?

Please tick all that apply

(a) Family/ friends/ acquaintances

Applicable

(b) Clubs

$\square 2$

tlaufmerka

(c) Tiryaki Kukla Event

$\square 2$

t1watchful

(d) Radio, television (in German or French)

$\square 2$

tlattentionc

(e) Radio, television (in Turkish)

$\square 2$

t1remarking

(f) Newspapers/ magazines (in German or French)

$\square_{2}$

tlobservations

(g) Newspapers/ magazines (in Turkish language)

$\square 2$

tlattention

tlattention

(h) Internet (e.g. www.stop-tabac.ch, www.at-schweiz.ch,

$\square 2$

tlattention consulate)

(i) health professionals (doctor, dentist, pharmacist, specialised institution, etc.)

(j) Posters, flyers, brochures in shops, restaurants etc.

(k) anti-smoking competition

(1) Smoke Stop Line (smokers' telephone)

tlattention

(m) Social media (Facebook, Twitter, Instagram, WhatsApp etc.

(n) Other:

30. How many people were you able to persuade to take part in this stop smoking course? number of people

31. Do you have wishes and expectations that you would share with us? 